\title{
1 \\ Introduction: Shaping the road pricing and provision debate
}

\author{
Michael de Percy
}

Road pricing in Australia is shaping up to be an incredibly important policy instrument to change the behaviour of road users and to address the decline in federal fuel excise revenues. The current system of recovering basic costs from road use treats roads as a free-access 'public good' and, aside from toll roads, users do not pay directly for their use of the road network or contribution to congestion. The present system of levy charging (fuel excise and registration charges) has little impact on the behaviour of road users and, if the current system remains unchanged, traffic congestion in metropolitan areas is set to cost some $\$ 30$ billion by 2030 (BITRE 2015). For most non-commercial road users, the cost of using the road network is limited to a fixed annual state government access charge (vehicle registration and licence fee) and the federal fuel excise (currently 40.1 cents per litre). However, since the early 2000 s, more fuel-efficient vehicles have reduced fuel usage overall and, consequently, revenue from the fuel excise has been steadily declining (BITRE 2016). Further, the existing user charges (fuel excise and vehicle registration) may discriminate marginally between vehicle types and capacities, but not between heavy and light users of roads (although heavy users will necessarily pay more fuel excise). Moreover, fuel excise is collected as consolidated revenue by the Commonwealth, and therefore provides no market signals on the demand for particular roads. Consequently, estimates used to direct road 
provision and maintenance routinely prove to be inaccurate, and often simply increasing the capacity of roads reinforces the behaviour that led to traffic congestion in the first instance.

Other networked infrastructure or utility services provided by governments - such as water, gas, power and telecommunications-have been provided on a user-pays basis since market reforms were introduced beginning in the late 1980s, yet the road network remains the least reformed infrastructure sector. This means that the change in behaviour evidenced in the efficient use of water, home heating, electrical power and telecommunications services-particularly in households_-is not evident in our patterns of road use. While user charging has been adopted on private sector-funded tunnels and tollways, these charges are based on investment returns and not on changing the behaviour of users across the network. Whereas reforms in other networked infrastructure sectors removed the model of effectively taxing businesses to cross-subsidise households, road funding models - by relying on indirect taxes that do not relate to the volume of usage - tend to cross-subsidise heavy users through light or even non-users of roads. Effectively, this leads to cross-subsidisation of road infrastructure and impacts on the supposedly competitive rail sector-hence the Australasian Railway Association's (2010: 21) support for the introduction of road pricing to ensure a level playing field between land transport modes. Further, where prices do not reflect volume of use, economic inefficiencies may result from externalities such as higher safety risks and further congestion and, subsequently, further degradation of roads. Changing transport behaviours is an important solution to traffic congestion, but the current system provides few incentives for users to reduce their reliance on road travel.

The primary purpose of a road user direct payment system (which might include volume-of-use charges combined with variable congestion charging during peak periods in central business districts) is to change commuter behaviour while at the same time rationalising road provision to better align it with strategic productivity considerations. Improvements in productivity require reduced traffic congestion and more effective use of transport infrastructure investment funds to deliver strategically important infrastructure. Building more and more roads into the future is unsustainable, and other approaches—such as changing traditional work and school hours - are unlikely to be achievable in the short term. Private sector investment entities have indicated that there are funds available for significant public-private partnerships (PPPs), and unsolicited 
infrastructure proposals, such as Transurban's recent East-West Link bid, are becoming an accepted way for governments to exploit infrastructure development opportunities.

But road reform is not just about roads. Transport reform may also contribute to other policy objectives, such as increasing physical activity or reducing environmental impacts through bicycle riding, the use of smaller vehicles (such as mopeds) or increased use of public transport. However, commuters are unlikely to change their behaviour under the current regime because existing road user charges are more akin to blunt access taxes, where, once paid, a consumer can exploit the provision to their heart's content. The charges convey negligible signals to road users about the costs of using particular roads, or to infrastructure providers about the demand for different roads. Furthermore, while investment in mass transit systems is under way-such as the Sydney and Melbourne metro systems, with major services opening in 2024-these systems will offer an alternative, large-scale option for commuters in Sydney and Melbourne. Introducing user charging to coincide with the availability of mass transit systems provides an ideal time to reform the planning, provision and maintenance of the road network, and incentivising behavioural changes that will help to decrease traffic congestion.

Previously, governments were prepared to tackle entrenched political obstacles to reform in introducing user-pays systems in public utilities and telecommunications services, but technological limitations, combined with entrenched interests, prevented reform of road pricing and provision. However, despite Professor Ian Harper's 2014 review of productivity acknowledging that technology is no longer an impediment to the implementation of a road user-pays system, and most transportrelated interest groups calling for a road pricing and hypothecated funding system, there has been remarkably little policy action to date (Harper et al. 2015). Indeed, increased road provision has recently become a major federal election policy platform, utilising the existing funding model. As a result, the policy problem has become much more than how to adopt a particular pricing regime that will cover construction costs while encouraging more efficient use of transport infrastructure. Indeed, numerous technological and institutional mechanisms are well advanced overseas, already in implementation and have proven capability in delivering transport infrastructure efficiencies. The policy problem in Australia-like many other policy problems - relates to the impetus for reform and lack of political prioritisation. For instance, within the 
transport industry more generally, there is broad support for road charging reform on a user-pays basis. Yet, when economic or political opinion leaders - as opposed to industry advocates - meet, transport reform tends to be relegated to the 'too-hard basket' and supplanted by seemingly more pressing macroeconomic issues. Some commentators may argue that a focus on economic restructuring remains a pressing priority, but this places the transport industry in a difficult position: reform is easily achievable technically, yet incredibly difficult to implement without the necessary political will or the incentives for commuters to accept reform. It is clear that transport reform cannot be achieved by the transport industry working in isolation; a consolidated reform effort is required.

This book addresses two major questions that need to be answered if reform of the road pricing and provision system is to stimulate policy debate outside the industry:

- How can the terms of the public debate concerning infrastructure planning, provision and pricing be 'shifted' to address the long-term problems that will be brought about by not acting?

- How can commuters and road users be encouraged to develop a better understanding of longer-term issues of choice, pricing and interoperability of transport infrastructure?

This book highlights the major challenges to reform by bringing together some of the latest thinking on road pricing and provision in Australia, along with case studies from Singapore and New Zealand. The book addresses issues relating to three major transport infrastructure policy themes developed in consultation with the Australian Department of Infrastructure and Regional Development: 1) finding ways to better align the long-term planning of transport infrastructure with usage and productivity imperatives; 2 ) tackling the array of political and attitudinal impediments to achieving better infrastructure pricing and user-pays modes of pricing; and 3) translating technical capabilities and economic pricing theories into practice. While the book is intended to inform and stimulate discussion about future directions for transport infrastructure policy, and argue for a more sustainable and systemic mode of cost recovery, it does not attempt to advocate a single preferred solution to the current policy problems. Indeed, specific (or even optimal) policy solutions designed to address traffic congestion or improve freight movement are often mired in conflict with existing political realities. Infrastructure planning is frequently overshadowed by other concerns, 
such as private property rights, privacy rights and entrenched interests that make it all but impossible for governments to put the broader public interest forcibly ahead of narrow self-interest. Nonetheless, as Australia's major metropolitan centres continue to grow and-as we will demonstrate later-fuel excise revenues continue to decline, better integrated planning and some form of co-contribution charging will become increasingly important to ensure Australia's continued productivity and a better quality of life for citizens and commuters. The Harper (Harper et al. 2015) and Henry (Henry et al. 2010) reviews acknowledged that road reforms are among the most difficult to implement and will need to be conducted as part of a broader tax reform package. This book aims to provide a platform for elevating transport reform beyond the bounds of the transport industry - an important first step if road pricing and provision are to become key parts of the current reform agenda.

The book is divided into four sections. In Chapter 2, I consider where we are now and how we got here in developing a system of pricing and provision of road infrastructure. It has been noted that road reform cannot be done in isolation, and we find the story of roads was intertwined with rail and coastal shipping from the earliest days. In Section 2, we look to the long-term planning aspects of transport infrastructure. Marion Terrill considers the ways to reframe transport planning in Australia by shifting the debate away from an investment-only focus on big projects to considering transport as a complex social system interconnected with many spheres of policy. Philip Davies discusses Infrastructure Australia's strategic role in infrastructure planning, the importance of long-term and intermodal planning and preparing for population growth in our major metropolitan areas. Expertise contributed by Teik Soon Looi provides a case study of Singapore's world-class transport management network, outlining the challenges in reducing reliance on private vehicles and trialling new technologies in user charging, introducing advanced big data analysis for demand management and, soon, autonomous vehicles. Singapore's example in using market signals and incentives and disincentives to radically change transport behaviours provides interesting food for thought. Singapore is one of the few Asian capital cities (along with Tokyo) where transport mobility is effortless and congestion has been almost eliminated; the quality of life and movement in these planned transport cities compares outstandingly with other regional centres such as Jakarta, Beijing or Bangkok. 
In Section 3, we look to how transport differs from other network technologies and at recent work on assessing the various options for road pricing and funding reform options. Alex Robson provides an economist's perspective on the difficulties governments will face in trying to convince motorists that reform is a good idea. He highlights how recent experience demonstrates how forecasts are rarely accurate and how a rigorous costbenefit analysis can help in reducing policy errors. Brendon Lyon argues for a detailed public inquiry into road pricing and outlines the user-based approach adopted by Infrastructure Partnerships Australia in assessing the various options for road pricing. Interestingly, since the release of Infrastructure Australia's 15-year plan (see Chapter 4), the Turnbull Government has announced that an 'eminent Australian' will be chosen to lead a study into the costs and benefits of road pricing in the near future. Peter Winder concludes this section with a case study of Auckland's recent attempt to address shortcomings in infrastructure funding. He argues for the necessity and value of making political trade-offs explicit and transparent, and ensuring all stakeholders clearly understand both the trade-offs and associated constraints in initiating reform.

In the final section, we consider how to turn theory into practice. Professor Gary Banks draws on his long experience as the head of the Productivity Commission to detail the practical problems of addressing the concerns of the winners and losers of reform processes. The National Competition Policy reforms often faced stiff opposition, but strong technical and advisory support within key departments and political offices, and the importance of 'policy champions', are among the many practical lessons from these past successes. He argues that the need for change must become part of the policy narrative and it is up to political leaders to make a well-argued case that reform will make life better for Australian citizens. John Wanna concludes with an assessment of the prospects for and feasibility of reform pathways proposed by a selection of the more influential recent reports. His assessment considers the opportunities and challenges entailed when weighing up the various reform options and, in particular, highlights the implications for federal-state relations.

This monograph seeks to advance the road reform agenda by presenting some of the latest thinking on road pricing and provision from a variety of disciplinary approaches. It stresses the need for reform to ensure Australians can enjoy the benefits of efficient and sustainable transport infrastructure as our population and major cities continue to grow. Traffic congestion is avoidable, but we must act soon. The chapters presented 
here all point to the need for change; the expertise and the technology are available, and the various reform options have been mapped out in some detail. It is time for the policy debate to shift to how-rather than whether-road reform should progress.

\section{References}

Australasian Railway Association. (2010). Road Pricing Reforms in Australia: Why Road Pricing is Vital to Australia's Economic Prosperity. Canberra: Australasian Railway Association.

Bureau of Infrastructure, Transport and Regional Economics (BITRE). (2015). Traffic and Congestion Cost Trends for Australian Capital Cities. Information Sheet 74, November. Canberra: Commonwealth of Australia.

Bureau of Infrastructure, Transport and Regional Economics (BITRE). (2016). Yearbook 2016: Australian Infrastructure Statistics. Statistical Report. Canberra: Commonwealth of Australia.

Harper, I., Anderson, P., McCluskey, S. and O'Bryan, M. (2015). Competition Policy Review: Final Report March 2015. Canberra: Commonwealth of Australia. Available from: competitionpolicyreview.gov.au/files/2015/03/ Competition-policy-review-report_online.pdf (accessed 12 August 2017).

Henry, K., Harmer, J., Piggott, J., Ridout, H. and Smith, G. (2010). Australia's Future Tax System: Report to the Treasurer, Detailed Analysis Volume 2. Canberra: Commonwealth of Australia. 
This text is taken from Road Pricing and Provision: Changed Traffic Conditions Ahead, edited by Michael de Percy and John Wanna, published 2018 by ANU Press, The Australian National University, Canberra, Australia.

doi.org/10.22459/RPP.07.2018.01 